\title{
Chapter 10 \\ Climate Sensitivity of Groundwater Systems in South India: Does It Matter for Agricultural Income?
}

\author{
R. Balasubramanian and V. Saravanakumar
}

\section{Key Messages}

- Flat or fully subsidized electricity pricing policy in Tamil Nadu negatively impacted groundwater table, implying that the subsidized pricing has lowered the water table.

- Increase in temperature had a negative impact on farm income, while increase in rainfall had a positive impact on net revenue. Increase in depth to water reduces farm income.

- An important policy implication of the analysis is the negative impact of well density beyond a threshold level on farm income.

\subsection{Introduction}

Groundwater is the source of about one-third of global water withdrawals and provides drinking water for a large portion of the global population. In many regions, it is subject to stress with respect to both quantity and quality (Kundzewicz \& Döll, 2009). Climate change will lead to significant changes in groundwater recharge and thus renewable groundwater resources (Döll, 2009). Climate change impacts may add to existing pressure on groundwater resources directly through changes in groundwater recharge (supply) and indirectly through changes in demand for groundwater (Taylor et al., 2013). Even though groundwater is the major source of water in most parts of the world, particularly in rural areas in arid and semi-arid regions, there has been limited research on the potential effects of climate change on groundwater

R. Balasubramanian $(\bowtie) \cdot$ V. Saravanakumar

Department of Agricultural Economics, Tamil Nadu Agricultural University, Coimbatore, India e-mail: rubalu@gmail.com

\section{Saravanakumar \\ e-mail: sharanu2k@gmail.com}


recharge and its quality (Alley, 2001; Bates et al., 2008). Therefore, understanding the impact of climate variability and change on the availability and sustainability of surface water and groundwater resources is of significant ecological and economic significance (Dragoni \& Sukhija, 2008). There is an evolving literature that looks at factors that affect farmer adaptation to climate change (Bahinipati \& Patnaik, 2021, Chap. 4 of this volume).

India is the largest user of groundwater globally with an estimated annual groundwater withdrawal of $230 \mathrm{~km}^{3}$. More than $60 \%$ of India's irrigated acreage and as much as $85 \%$ of rural India's drinking water requirement is met from groundwater. Western and peninsular India is groundwater hotspots from a climate change point of view (Shah, 2009). In spite of the intricate interrelationship between climate variables and groundwater and the growing significance of groundwater in sustaining agricultural productivity, systematic studies on impact of climate and non-climate variables on groundwater balance and agricultural production are very limited in India. This study is an attempt to fill this void through a systematic analysis of climate-groundwateragriculture nexus. The chapter is organized as follows: in the following section, we review key issues and challenges posed by climate change for groundwater in general and its specific implications for groundwater-dependent agriculture. The next section describes the study area and the sources of data. The section on methods deals with the theoretical model and empirical strategy for econometric estimation, while the subsequent section presents and discusses the key results of the study. The final section presents the conclusions and policy recommendations emerging from the study.

\subsection{Climate Change and Groundwater Irrigation ${ }^{1}$}

\subsubsection{Impact of Climate Variables on Groundwater Dynamics}

Global warming is expected to cause lower water tables and reduce groundwater availability, while the extraction of groundwater is likely to increase to meet the growing demand (Okkonen et al., ). Climate variability directly affects rain-fed agricultural production through changes in supply of soil moisture and indirectly affects irrigated agriculture through its impact on surface water runoff and groundwater recharge. Two broad approaches have been used to study the impact of climate change on groundwater resources. The first is a physical approach wherein the changes in groundwater reserves are quantified by physical measurements using hydrological modelling such as water balance method or GIS and simulation modelling. The second is a statistical modelling approach where the changes in groundwater

\footnotetext{
${ }^{1}$ A significant portion of the materials is drawn with permission from author's working paper: Balasubramanian (2015). Climate Sensitivity of Groundwater Systems Critical for Agricultural Incomes in South India, SANDEE Working Paper No 96-15.
} 
levels are estimated through building statistical relationship between groundwater level and rainfall, temperature and other variables. Regression analysis incorporating climate- and/or non-climate variables has been used by many researchers to study the impact of these variables on water table levels (Balasubramanian, 1998; Ferguson and George, 2003; Ngongondo, 2006; Palanisami \& Balasubramanian, 1993). Using regression analysis of groundwater levels with monthly rainfall data, Bloomfield et al. (2003)predicted groundwater levels under different future climates and found that even with a small increase in total annual rainfall, annual groundwater level could fall in the future due to changes in seasonality and increased frequency of drought events. Chen et al. (2001) used a log-log regression model to study the impact of temperature and rainfall on groundwater table.

\subsubsection{Climate Change and Irrigated Agriculture}

There are two distinct but interrelated issues concerning the treatment of irrigation in economic studies on climate change impact on agriculture: (a) the issue of climate sensitivity of irrigated vs. rain-fed farms, which is about carrying out separate or pooled analysis of climate change impact for irrigated and rain-fed farms; and (b) the inclusion of irrigation as one of the explanatory variables in the regression model. The early Ricardian models did not account for irrigation in analysing climate change impact and ignored both of these issues. As the supply and demand for irrigation water are affected by climate change, inclusion of irrigation as an explanatory variable is important. However, studies that have explicitly incorporated groundwater availability and/or withdrawal in climate change impact models in Indian agriculture are very limited. Though a few studies have incorporated groundwater irrigation in economic models of climate change impact on agriculture, these have not studied dual effects of climate change directly on production agriculture and its impact via groundwater on agricultural productivity and/or farm income using an econometric approach. For example, Schlenker et al. (2007) examined the impact of climate variables, surface water availability and depth to groundwater on irrigated agriculture in California using Ricardian analysis using farmland value for 2555 farms as the dependent variable. Their analysis shows that while surface water availability had significant positive impact on farmland values, depth of groundwater table was not statistically significant. Though a study by Chen et al. (2001) estimated both climate change impact on groundwater and its subsequent impact on regional economy including agriculture, it has used mathematical programming and simulation modelling to quantify economic impacts. 


\subsection{Study Area and Data}

\subsubsection{Description of Study Site}

This study was carried out in the southern Indian state of Tamil Nadu where groundwater aquifers are under severe stress due to poor management caused by perverse incentives such as fully subsidized electricity for groundwater pumping. Tamil Nadu is located in the southernmost part of India and is divided into seven agro-climatic regions with a wide diversity in climate and crops cultivated. The average annual rainfall varies from 650 to $1350 \mathrm{~mm}$ in the plains, and the average annual maximum temperature varies from 31 to $34.50{ }^{\circ} \mathrm{C}$. Groundwater irrigation in the state has expanded rapidly in the last five decades due to the decline and/or instability in surface irrigation sources, massive expansion in rural electrification, the advent of modern well-drilling technologies and subsidized supply of electricity for groundwater pumping. Groundwater overexploitation is reported in more than one-third of blocks ${ }^{2}$ in Tamil Nadu (CGWB, 2012).

While the total area irrigated from surface irrigation sources such as tanks and canals decreased considerably from more than 1.80 million ha in 1960-61 to about 1.30 million ha in 2010, the total number of groundwater wells has increased from about 0.87 million to 1.90 million and the area irrigated by wells has increased from 0.6 million ha in 1965 to 1.6 million ha in 2016. Electricity pricing for agricultural pumping underwent significant changes over time from a pro-rata tariff until the early 1980 s, to a system of flat tariff in late 1980s and finally to a fully subsidized (100\% subsidy) electricity supply for agriculture from 1990 to 91 onward. The introduction of "zero-marginal-cost" pricing of electricity (after the flat-rate tariff was introduced), along with the advent of low-cost well-drilling technologies have provided added impetus to the drilling of deep bore wells in the last two decades. As a result, the State of Tamil Nadu has become one of the groundwater hotspot areas in India which makes it an ideal location to study the climate change impact on groundwater resources.

\subsubsection{Data Sources}

Time-series data on water-level data from 1740 observation wells over a period of 40 years from 1971 to 2010 and the corresponding data on rainfall, temperature, number of groundwater wells and surface water sources and area of various crops cultivated with groundwater and surface water irrigation, and other socioeconomic variables such as population and urbanization were collected from Government publications. Spatial distribution of observation wells across the entire state with different

\footnotetext{
${ }^{2}$ Blocks are the bottom-most unit in the administrative hierarchy in the State. The data on groundwater recharge and pumping volumes are estimated at block level.
} 
endowments of surface water resources, aquifer formations and related hydrogeological and socio-economic factors were used to divide the entire state into several cross-sectional units. The water-level data for 1740 individual wells was compressed into district-level averages which will help conduct panel data analysis of groundwater table fluctuations vis-à-vis climatic and non-climatic variables, with districts serving as cross-sectional units (panels). During the period of 40 years from 1971 to 2010, for which the water-level data is available, electricity pricing for groundwater pumping, institutional arrangements for groundwater management, availability and performance of other sources of irrigation like canals and tanks, and the technology for well-drilling have undergone significant changes. We incorporate these variables in our model.

The second part of the analysis, which is concerned with the impact of climatic factors along with groundwater level changes on agricultural crop production, relies on agricultural crop production data at district-level to estimate net revenue per hectare from crop production. Data on crop-wise, district-level average productivity (yield in $\mathrm{kg} / \mathrm{ha}$ ) were sourced from Season and Crops Reports for Tamil Nadu, published by the Government of Tamil Nadu over the entire study period from 1971 to 2010. Data on input quantities and costs were assembled from the Government of India Scheme on Cost of Cultivation of Principal Crops being implemented in the Department of Agricultural Economics, Tamil Nadu Agricultural University. Using these two sets of data on input quantities, yield and input and output prices, estimates on average net income per hectare for 11 districts of Tamil Nadu were constructed for 40 years (1971-2010).

\subsection{Methods}

\subsubsection{Empirical Model}

Though several studies used Ricardian model to estimate climate change impact, Deschênes and Greenstone (2007) proposed an alternative to cross-sectional Ricardian approach by using random, year-to-year variability in weather parameters such as precipitation and temperature on farm profits. Consequently, this approach allows the use of panel data model, to estimate the effect of weather on farm profits, conditional on locations by year fixed effects. Kumar (2011) used this approach in his analysis of 271 Indian districts over a period of 20 years to estimate the impact of climate change on farm net revenue. Following these studies, the empirical, panel data econometric model of our study consists of a set of two equations - the first one concerning the impact of climate and non-climate factors on groundwater table and the second one concerning the impact of climate, water and other economic factors affecting farm income.

$$
\text { Watlev }_{\text {it }}=\alpha_{0}+\alpha_{1} \text { Lwatlev }+\alpha_{2} \text { Rain }+\alpha_{3} \text { Lrain }
$$




$$
\begin{aligned}
& +\alpha_{4} \text { Tmax }+\alpha_{5} \text { Watint }+\alpha_{6} \text { Lwatint } \\
& +\alpha_{7} \text { Elecdum }+\alpha_{8} \text { Tankgia }+\alpha_{9} \text { Canalgia }+\alpha_{10} \text { Time }
\end{aligned}
$$

Equation (10.1) was estimated using dynamic panel data approach in view of the presence of lagged dependent variable as one of the regressors.

The equation for net returns is specified as shown below, and it was estimated using aggregate district-level data rather than farm-level data. In the net returns equation, we use the estimated depth to water table from Eq. 10.1. In addition to the depth to water table, climate variables, dummy for districts (coastal and non-coastal), dummy for electricity price, well density, indices of input and output prices were also used as explanatory variables.

$$
\begin{aligned}
\text { Return }= & \gamma_{0}+\gamma_{1} \text { Rain }_{i t}+\gamma_{2} \text { Rain }^{2}+\gamma_{3} \text { Tmax } \\
& +\gamma_{4} \operatorname{Tmax}^{2}+\gamma_{5} \text { Distdum }+\gamma_{6} \text { Wellden } \\
& +\gamma_{7} \text { Wellden }^{2}+\gamma_{8} \text { Elecdum }+\gamma_{9} \text { Ewatlev } \\
& +\gamma_{10} \text { Inprice }+\gamma_{11} \text { Outprice }+\gamma_{12} \text { Time }+\gamma_{13} \text { Surfgia }
\end{aligned}
$$

where

Return $=$ Net farm income from crop production

Rain = Rainfall $(\mathrm{mm})$

Tmax $=$ Max. temperature $\left({ }^{\circ} \mathrm{C}\right)$

Distdum $=$ District dummy $(0=$ Coastal district; $1=$ Non-coastal district $)$

Wellden $=$ Well density (total number of wells per ha of geographical area of the $i$ th district)

Elecdum $=$ Dummy for electricity price $(=0$ for pro-rata tariff; $=1$ for flat rate or full subsidy)

Ewatlev = Estimated water level from Eq. 10.1

Inprice $=$ Weighted average of input prices

Outprice $=$ Weighted average of output prices

Time $=$ Time $($ Trend variable $)$

Surfgia $=$ Proportion of surface irrigated area to gross irrigated area by all sources

Tankgia $=$ Gross irrigated area by tanks (ha)

Canalgia $=$ Gross irrigated area by canals (ha)

Watlev $=$ Groundwater level (in metres below surface)

Lwatlev $=$ One-period lag of groundwater level

Watint $=$ Share of water-intensive crops to gross cropped area

Lwatint $=$ One-period lag of share of water-intensive crops to gross cropped area. 


\subsubsection{Estimation Strategy}

The first equation was estimated using spatial dynamic panel method due to the presence of lagged dependent variable as one of the explanatory variables in the model. The model was estimated with two-period lag structure, using ArellanoBond estimators for spatial dynamic panel model (Arellano \& Bond, 1991). The net revenue equation was estimated using panel-corrected standard errors regression model using estimated water level from the first equation as one of the explanatory variables. Descriptive statistics of the variables are presented in Table 10.1.

Table 10.1 Definition of variables and their descriptive statistics

\begin{tabular}{|c|c|c|c|c|c|c|}
\hline Variable & Definition & $N$ & Mean & Std. dev & Min & Max \\
\hline Watlev & Depth to water table (m) & 440 & 7.46 & 2.69 & 3.25 & 16.44 \\
\hline Rain & Rainfall (mm) & 440 & 969.24 & 344.87 & 305.1 & 2106.95 \\
\hline Rain $^{2}$ & Square of rainfall & 440 & $1,058,096$ & 749,672 & 93,086 & $4,439,238$ \\
\hline Lrain & Lagged rainfall & 429 & 963.43 & 342.42 & 305 & 2107 \\
\hline Tmax & Max. temperature (C) & 440 & 33.03 & 1.07 & 30.53 & 35.26 \\
\hline $\operatorname{Tmax}^{2}$ & Square of max temperature & 440 & 1091.97 & 70.49 & 932.08 & 1243.27 \\
\hline Time & Trend variable (year) & 440 & 20.50 & 11.56 & 1.00 & 40.00 \\
\hline Canalgia & $\begin{array}{l}\text { Gross irrigated area by canals } \\
\text { ('000 ha) }\end{array}$ & 440 & 82.01 & 131.28 & 0.00 & 650.76 \\
\hline Tankgia & $\begin{array}{l}\text { Gross irrigated area by tanks } \\
\text { ('000 ha) }\end{array}$ & 440 & 65.31 & 64.74 & 0.168 & 696.46 \\
\hline Watint & $\begin{array}{l}\text { Share of area under } \\
\text { water-intensive crops }\end{array}$ & 440 & 0.44 & 0.21 & 0.047 & 0.98 \\
\hline Returns & Net returns & 440 & 17,715 & 6961 & 4201 & 43,986 \\
\hline Elecdum & $\begin{array}{l}\text { Dummy for electricity price }(0 \text { for } \\
\text { pro-rata price; } 1=\text { for flat or zero } \\
\text { tariff) }\end{array}$ & 440 & 0.65 & 0.48 & 0.00 & 1.00 \\
\hline Distdum & Dummy for coastal districts & 440 & 0.73 & 0.45 & 0.00 & 1.00 \\
\hline Wellden & $\begin{array}{l}\text { Well density (No. per } \mathrm{km}^{2} \text { of } \\
\text { geographical area) }\end{array}$ & 440 & 0.11 & 0.06 & 0.0018 & 0.28 \\
\hline Wellden $^{2}$ & Square of well density & 440 & 0.017 & 0.017 & 0.00001 & 0.08 \\
\hline Inprice & Weighted average input price & 440 & 43.47 & 8.94 & 31.80 & 119.81 \\
\hline Outprice & Weighted average of output prices & 440 & 21.00 & 16.49 & 1.32 & 89.71 \\
\hline
\end{tabular}

Source Field data 


\subsection{Results and Discussion}

\subsubsection{Impact of Climate Change on Groundwater Dynamics}

Climatic variables, viz., both current period and one-period lagged rainfall, as well as maximum temperature were found to be statistically significant in impacting the groundwater table. As expected, maximum temperature had a positive impact on depth to groundwater table which is the direct result of increased evapotranspiration which in turn would result in lower recharge as well as higher withdrawal of groundwater to compensate for evapotranspiration. Similarly, rainfall had negative impacts on depth to groundwater table as higher rainfall results in higher recharge thus resulting in reduced depth to (or a rise in) groundwater table. The estimated elasticity values indicate that temperature has a much higher impact on water levels than rainfall. A $1 \%$ increase in temperature is found to increase the depth of the water level by more than $1 \%$, whereas a $1 \%$ increase in current period rainfall and lagged rainfall would reduce the depth of the water table only by a meagre 0.08 and $0.15 \%$, respectively. Using the regression coefficients for current period rainfall and temperature, it could be seen that to offset an increase in temperature by $1{ }^{\circ} \mathrm{C}$, the current rainfall increases by about $193 \mathrm{~mm}$. A $1 \%$ increase in other variables such as share of water-intensive crops in the previous year, share of tank irrigated area to gross irrigated area, and the trend variable had $0.03-0.04 \%$ reduction in the depth of the water table. The dummy variable for electricity pricing results in an increased depth to the water table indicating that zero-marginal cost for water pumping induced farmers to pump more water thereby causing a drop in the water table. The overall explanatory power of the model as indicated by Wald Chi-square is found to be statistically highly significant at less than $1 \%$ level indicating that the model is a good fit for the data. The results of dynamic panel data regression model are presented in Table 10.2.

\subsubsection{Climate Change, Groundwater Dynamics and Farm Income}

The second part of the econometric exercise is concerned with the estimation of net returns equation in which the estimated values of change in depth to water table and tank irrigated area from the previous section of econometric analysis were used as explanatory variables along with other exogenous variables. The results of the panel-corrected standard error regression analysis are presented in Table 10.3. All the independent variables except the linear term of rainfall were found to be statistically significant. The coefficients of temperature and its quadratic terms indicate that net returns per hectare increase with increase in temperature up to a point beyond which it starts declining. The threshold level of temperature which results in maximum net returns is found to be $39.20^{\circ} \mathrm{C}$. In a study of rural income and climate change in the 
10 Climate Sensitivity of Groundwater Systems in South India ...

Table 10.2 Dynamic panel estimation of depth to water table

\begin{tabular}{l|c|l|l|c}
\hline Variables & Coef & Robust Std. err & $z$ & Elasticity \\
\hline Lwatlev & $0.70^{* * *}$ & 0.04 & 16.65 & 0.70 \\
\hline Rain & $-0.001^{* *}$ & 0.0003 & -1.98 & -0.08 \\
\hline Lrain & $-0.001^{* * *}$ & 0.0002 & -4.96 & -0.15 \\
\hline Tmax & $0.23^{* * *}$ & 0.08 & 2.9 & 1.01 \\
\hline Watintsh & -0.53 & 0.77 & -0.69 & -0.03 \\
\hline Lwatintsh & $0.71^{*}$ & 0.43 & 1.67 & 0.04 \\
\hline Elecdum & $0.50^{* * *}$ & 0.14 & 3.61 & 0.04 \\
\hline Tankgia & $-0.004^{* *}$ & 0.002 & -1.96 & -0.04 \\
\hline Canalgia & -0.001 & 0.001 & -1.28 & -0.01 \\
\hline Time & $-0.025^{* * *}$ & 0.008 & -3.28 & -0.07 \\
\hline Cons & $-3.115^{* * *}$ & 2.95 & -1.06 & \\
\hline Wald Chi2 & $42,915.35$ & & Prob $>$ chi2 $=0$
\end{tabular}

Arellano-Bond test for AR(2) in first differences: $z=1.33 \operatorname{Pr}>z=0.182$

Sargan test of overid. restrictions: $\operatorname{chi} 2(338)=421.39$ Prob $>$ chi $2=0.001$

Source Field data

Table 10.3 Panel-corrected standard errors regression estimation of net returns

\begin{tabular}{|c|c|c|c|c|c|}
\hline Variables & Coef & Std. Err & $z$ & $P>z$ & Elasticity \\
\hline Rain & 1.61 & 1.07 & 1.5 & 0.134 & -0.0043 \\
\hline Rain $^{2}$ & $-0.00^{*}$ & 0.00 & -1.86 & 0.063 & \\
\hline Tmax & $44,537.90^{* * *}$ & $12,675.89$ & 3.51 & 0 & 0.74 \\
\hline $\operatorname{Tmax}^{2}$ & $-667.73^{* * *}$ & 191.36 & -3.49 & 0 & \\
\hline Distdum & $4278.86^{* * *}$ & 779.78 & 5.49 & 0 & 0.16 \\
\hline Ewatlev & $-639.74^{* * *}$ & 216.84 & -2.95 & 0.003 & -0.25 \\
\hline Inprice & $-131.77^{* * *}$ & 35.17 & -3.75 & 0 & -0.30 \\
\hline Outprice & $195.25^{* * *}$ & 34.04 & 5.74 & 0 & 0.21 \\
\hline Time & $89.49^{*}$ & 51.28 & 1.75 & 0.081 & 0.10 \\
\hline Elecdum & $2341.08^{* *}$ & 1096.52 & 2.14 & 0.033 & 0.08 \\
\hline Surfgia & $-10,803.55^{* * *}$ & 1760.08 & -6.14 & 0 & -0.27 \\
\hline Wellden & $93,494.50^{* * *}$ & $19,150.87$ & 4.88 & 0 & 0.061 \\
\hline Wellden $^{2}$ & $-369,441.90^{* * *}$ & $49,564.53$ & -7.45 & 0 & \\
\hline Constant & $-722,676.20^{* * *}$ & $209,380.50$ & -3.45 & 0.001 & \\
\hline \multicolumn{2}{|c|}{ R-squared $=0.6270$} & $\mathrm{~d}$ chi $2=.851$ & & \multicolumn{2}{|c|}{ Prob $>$ chi $2=0.00$} \\
\hline
\end{tabular}

Source Field data 
US and Brazil, Mendelsohn \& Seo (2007) found that both agricultural net income and total rural income are affected by climate, and regions with poorer climates have more rural poverty.

The estimated water level from the first equation, which was used as one of the regressors in this model, turned out to be statistically significant. The elasticity value indicates that an increase in depth to water table by $1 \%$ reduces the net returns by about $0.25 \%$. The regression coefficient of trend (time) variable which could be expected to capture technological progress over time has turned out to be positive and significant indicating that net returns at constant prices have increased over time probably due to technological progress in agriculture. A dummy variable was used to differentiate between coastal and non-coastal districts in view of their significant differences in crop pattern, intensity and distribution of rainfall, and soil type. This variable has turned out to be statistically significant indicating that non-coastal districts have higher net returns as compared to their coastal counterparts. This is primarily because the coastal districts are predominantly paddy-based agricultural production systems where the net returns are lower. Further, distribution of rainfall is often skewed in coastal districts with heavy rains during the north-east monsoon. Increasing salinity and drainage problems in these districts could also have contributed to lower net farm incomes in coastal districts. We included both a linear and a quadratic term for well density as Tamil Nadu is witnessing a steep increase in the number of wells resulting in significant spatial externalities and poorer water yield per well. The regression estimates reveal that the coefficient for linear term was positively significant and the quadratic term was negatively significant. This implies that, ceteris paribus, an increase in number of wells per hectare of land might initially contribute for an increased net return, while the increase in well density beyond a threshold might result in reduced net returns per hectare of land due to intense rivalry in sharing scarce groundwater reserves. Using the results of the regression analysis, it was estimated that the optimal number of wells was 0.13 per ha of geographical area. Both the input and output price indices turned out to be statistically significant with expected signs.

The previous pro-rata pricing of electricity for groundwater pumping in the state has been replaced by the flat-rate system of electricity pricing in the late 1980s and fully subsidized supply of electricity for agricultural pumping from the year 1990 91 and has significantly altered the balance of economic access to groundwater. Large and medium farmers with access to capital started sinking deep bore wells thus depriving the small farmers of their reasonable share of groundwater resources. The race for groundwater has become further exacerbated by the advent of modern well-drilling technologies at a lower cost. This has, however, resulted in many of the small, but moderately well-off farmers joining the race for increasingly scarce groundwater resources. Steep increase in the number of deep bore wells with poor water yields, fitted with compressor pumps to enable continuous water extraction, with zero-marginal costs (thanks to flat-rate pricing or free electricity) has become a harsh reality in many parts of the state spelling doom for groundwater conservation efforts. It is therefore appropriate to include a dummy variable to capture the impact of introduction of zero-marginal cost pricing of electricity for irrigation. This variable 
has turned out to be statistically significant indicating that the provision of fully subsidized electricity to agriculture has in fact increased the net returns in agriculture probably because of the increased acreage under high-value crops even though some of these crops are water-intensive.

\subsection{Conclusions and Policy Recommendations}

This study has quantified the impact of climatic and non-climatic factors on groundwater level and its consequences for net farm income. It used panel data econometric analysis of data on groundwater levels from more than 1700 observation wells spread over the entire state, and the data on costs and returns from crop production for 11 districts (panels), over a period of 40 years from 1971 to 2010. The econometric analysis of depth to water table reveals that climate variables viz., current and oneperiod lagged rainfall had significant effect in reducing the depth to water table, while the share of area under water-intensive crops and maximum temperature had significant role in increasing the depth to (pushing down) water table. Flat or fully subsidized electricity pricing policy that resulted in zero-marginal cost of pumping has had a negative impact on groundwater table, implying that the recent subsidized pricing has lowered the water table. The analysis of climatic and non-climatic factors affecting net farm revenue revealed that both temperature and its quadratic term had expected signs and turned out to be statistically significant, while rainfall had a positive impact on net revenue. The depth to water table had expected sign and turned out to be statistically significant indicating that an increase in depth to water reduces farm income.

An important policy implication of the analysis is the negative impact of well density beyond a threshold level on farm income. The import of this result is the need for regulating the sinking of new wells, especially deep bore wells. Though free electricity has increased the average farm net revenues as indicated by the positive regression coefficient for electricity price dummy, there is a huge social cost due to full subsidy for electricity for pumping - both in terms of cost of electricity generation as well as the significant negative impact of electricity subsidy in increasing the depth to water table. This points to the need for considering the removal of free electricity as one of the mechanisms to regulate the unfettered growth of deep bore wells. The question of removal of electricity subsidy and regulation of well density puts both the policy makers and the farmers in a tight spot with regard to conserving groundwater in the current political climate. This is because the short-term interests of both farmers (especially the large-farmer lobby), and politicians will be betterserved if the subsidies continue, while the continuance of subsidies could thwart groundwater conservation efforts. Therefore, convincing farmers to opt for pro-rata electricity pricing in exchange for increased public investments and/or subsidies for recharge programs and farm-level water conservation investments should receive top priority in the future. This has the potential to foster the development of sustainable 
groundwater management solutions and more equitable distribution of access and opportunities.

The shift to water-intensive crops such as coconut and sugarcane in response to increasing labour scarcity is a major contributing factor for increased groundwater extraction. The distributional implications of cultivation of water-intensive crops by mostly economically well-off farmers has to be further studied since the present study is based on average net revenues at district level, and hence cannot throw light on who gains and who loses from groundwater overexploitation. However, a few studies in the past found that it is the poor farmers who will lose in the long-run since reaching down to groundwater at deeper aquifers is a capital-intensive venture which is affordable only for large and affluent farmers. Groundwater overexploitation and the consequent spatial (inter-well), and inter-temporal (intra- and intergenerational) externalities need to be carefully analysed, since both increasing the number of wells as well as deepening of existing wells could further exacerbate the situation. In view of the intensifying race for groundwater and the attendant externalities, appropriate institutional arrangements to regulate digging new wells and deepening existing wells are needed in order to manage scarce groundwater resources in a sustainable way. Though farmers respond to market signals in deciding the crop pattern and regulatory mechanisms could play a very little role, appropriate incentive structure such as subsidies for water-saving crops and/or technologies could be considered as alternative mechanisms to discourage the cultivation of water-intensive crops in groundwater hotspot areas. Public and private investments in groundwater recharge such as watershed development, percolation ponds, recharge wells and farm ponds should be stepped up in future. Efforts to revive traditional systems like the Small Tank Cascade Systems (STCS) of Sri Lanka (Vidanage et al., 2022, Chap. 15 of this volume) and innovative rainwater harvesting technology in mountain villages in Nepal (Kattel \& Nepal, 2021, Chap. 21 of this volume) are potential strategies that are available for replication.

Acknowledgements The research was supported financially and technically by the South Asian Network for Development and Environmental Economics (SANDEE) at the International Centre for Integrated Mountain Development (ICIMOD). We are grateful to Céline Nauges, Priya Shyamsundar, other SANDEE resource persons and peers for their critical comments and encouragement.

\section{References}

Alley, W. M. (2001). Groundwater and climate. Groundwater, 39, 161.

Arellano, M., \& Bond, S. R. (1991). Some tests of specification for panel data: Monte Carlo evidence and an application to employment equations. Review of Economic Studies, 58, $277-297$.

Bahinipati, C. S., \& Patnaik, U. (2021). What motivates farm level adaptation in India? A systematic review. In A. K. E. Haque, P. Mukhopadhyay, M. Nepal, \& M. R. Shammin (Eds.), Climate change and community resilience: Insights from South Asia (pp. 49-68). Springer. 
Balasubramanian, R. (1998). An enquiry into the nature, causes and consequences of growth of well irrigation in a Vanguard agrarian economy, Ph.D. thesis submitted to the Department of Agricultural Economics, Tamil Nadu Agricultural University, Coimbatore, India

Balasubramanian, R. (2015). Climate sensitivity of groundwater systems critical for agricultural incomes in South India. SANDEE Working Paper No 96-15.

Bates, B. C., Kundzewicz, Z. W., Wu, S., \& Palutikof, J. P. (Eds.). (2008). Climate change and water. Technical Paper of the Intergovernmental Panel on Climate Change (pp. 210). IPCC Secretariat.

Bloomfield, J. P., Gaus, I., \& Wade, S. D. (2003). A method for investigating the potential impacts of climate-change scenarios on annual minimum groundwater levels. Water and Environment Journal, 17(2), 86-91.

Central Groundwater Board. (2012). Aquifer systems of Tamil Nadu and Puducherry. Southern Regional Office, Ministry of Water Resources, Government of India, Chennai.

Chen, C., Gillig, D., \& McCarl, B. A. (2001). Effects of climate change on a water dependent regional economy: A study of the Texas Edwards aquifer. Climate Change, 49, 397-409.

Deschênes, O., \& Greenstone, M. (2007). The economic impacts of climate change: Evidence from agricultural output and random fluctuations in weather. The American Economic Review, 97(1), $354-385$.

Döll, P. (2009). Vulnerability to the impact of climate change on renewable groundwater resources: A global-scale assessment. Environment Research Letters, 4, 1-12.

Dragoni, W., \& Sukhija, B. S. (2008). Climate change and groundwater-A short review. In W. Dragoni \& B. S. Sikhija (Eds.), Climate change and groundwater (vol. 288, pp. 1-12). Geological Society, Special Publications London.

Ferguson, G., \& Scott, S. G. (2003). Historical and estimated ground water levels near Winnipeg, Canada, and their sensitivity to climatic variability. Journal of the American Water Resources Association, 39(5), 1249-1259.

Kattel, R. R., \& Nepal, M. (2021). Rainwater harvesting and rural livelihoods in Nepal. In A. K. E. Haque, P. Mukhopadhyay, M. Nepal, \& M. R. Shammin (Eds.), Climate change and community resilience: Insights from South Asia (pp. 159-173). Springer.

Kumar, K. S. K. (2011). Climate sensitivity of Indian agriculture: Do spatial effects matter? Cambridge Journal of Regions, Economy and Society, 4, 221-235.

Kundzewicz, Z. W., \& Döll, P. (2009). Will groundwater ease freshwater stress under climate change? Hydrological Sciences Journal, 54(4), 665-675.

Mendelsohn, R., \& Seo, N. (2007). Changing farm types and irrigation as an adaptation to climate change in Latin American agriculture, World Bank Policy Research Working Paper, 4161. The World Bank, Washington D.C.

Ngongondo, C. S. (2006). An analysis of long-term rainfall variability, trends and groundwater availability in the Mulunguzi river catchment area, Zomba mountain, Southern Malawi. Quaternary International, 148, 45-50.

Okkonen, J., Jyrkama, M., \& Kløve, B. (2010). A conceptual approach for assessing the impact of climate change on groundwater and related surface waters in cold regions (Finland). Hydrogeology Journal, 18, 429-439.

Palanisami, K., \& Balasubramanian, R. (1993) Overexploitation of groundwater resource-Experiences from Tamil Nadu. In M. Moench (Ed.), Water management: India's groundwater challenge. VIKSAT/Pacific Institute.

Schlenker, W., Hanemann, W. M., \& Fisher, A. C. (2007). Water availability, degree days, and the potential impact of climate change on irrigated agriculture in California. Climatic Change, 81(1), 19-38.

Shah, T. (2009). Climate change and groundwater: India's opportunities for mitigation and adaptation. Environmental Research Letters, 4, 1-13. 
Taylor, R., Scanlon, B., Döll, P., et al. (2013). Ground water and climate change. Nature Climate Change, 3, 322-329.

Vidanage, S. P., Kotagama, H. B., \& Dunusinghe, P. M. (2022). Sri Lanka's small tank cascade systems: Building agricultural resilience in the dry zone. In A. K. E. Haque, P. Mukhopadhyay, M. Nepal, \& M. R. Shammin (Eds.), Climate change and community resilience: Insights from South Asia (pp. 225-235). Springer.

Open Access This chapter is licensed under the terms of the Creative Commons AttributionNonCommercial-NoDerivatives 4.0 International License (http://creativecommons.org/licenses/bync-nd/4.0/), which permits any noncommercial use, sharing, distribution and reproduction in any medium or format, as long as you give appropriate credit to the original author(s) and the source, provide a link to the Creative Commons licence and indicate if you modified the licensed material. You do not have permission under this licence to share adapted material derived from this chapter or parts of it.

The images or other third party material in this chapter are included in the chapter's Creative Commons licence, unless indicated otherwise in a credit line to the material. If material is not included in the chapter's Creative Commons licence and your intended use is not permitted by statutory regulation or exceeds the permitted use, you will need to obtain permission directly from the copyright holder.

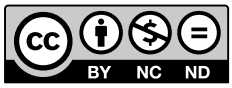

